\title{
Jeremy Garlick
}

University of Economics, Prague

http://dx.doi.org/10.18778/8142-287-1.08

\section{China-EU Energy Security Cooperation: The Case for Renewables ${ }^{1}$}

\begin{abstract}
The idea of China and the European Union cooperating on energy security is one which may not seem logical or likely at first glance. The two actors are geographically distant from one another and their energy supply needs and routes do not intersect for the most part. Yet careful study of the possibilities reveals that there is not only the potential, but also the need for cooperation on energy security. This is particularly the case in the field of renewables, where there is an opportunity to achieve win-win synergies which can produce enhanced outcomes in terms of local and global energy production and consumption.
\end{abstract}

Keywords: energy security, China-EU relations, Belt and Road Initiative, Juncker Plan, renewable energy, fossil fuels, nuclear energy

\section{Introduction}

In 2012 China and the European Union published a joint declaration on energy security. This suggested that there was a desire on both sides to cooperate on improving access to energy. The impression was deepened

1 This article is based on research conducted during the writing of an article entitled "An elusive synergy: the quest for cooperation on energy security between China and the European Union." This was published in Issues \& Studies, vol. 53, no. 3. Financial support for this article was provided by the Internal Grant Agency of the Faculty of International Relations, University of Economics, Prague, as part of the research project "The New Silk Road Initiative as a New Stage of Chinese Global Activity," project no. F2/32/2017. 
by the issuing of another joint declaration in 2013. It seemed as if China and the EU were determined to find common ground and take a real step forward on working in tandem towards improved energy security, in both the traditional and non-traditional sense.

However, since the joint declarations were made there has not been much substantive progress towards genuine cooperation. In short, the fine words of the declarations have not been translated into steps towards true collaboration in any real sense. Europeans have become preoccupied with other issues, such as migration and European unity (Brexit), while China has intensified its focus on bilateral relations with individual countries at the expense of developing a relationship of enhanced mutual trust with Brussels.

This paper analyses the potential for cooperation between China and the EU on energy security. The analysis suggests that while, for a range of reasons, there is a relatively low probability of substantive collaboration in the area of fossil fuels such as oil, coal and natural gas, as well as in nuclear energy, there is considerable potential for the two sides to work together on developing sources of renewable energy, such as solar and wind power. However, to do so a range of obstacles need to be overcome. Foremost among these are: (i) a lack of vision concerning the viability of renewables in an economic sense on the European side; (ii) intersubjective issues such as the absence of trust, particularly on the European side; (iii) the failure of Chinese companies to communicate their intentions concerning renewables clearly.

In order to accomplish the analysis, the paper will progress through the following steps. First, the concept of energy security will be examined in order to establish a working conceptualisation and definition for the purposes of this paper. Second, the background to EU-China energy security cooperation will be analysed. Third, the state of the EU's energy security will be examined, and, after that, China's energy security. Subsequently, the potential for cooperation on energy security between the two actors will be analysed. At the end, the conclusions concerning the possibilities for collaboration on energy security, particularly in the area of renewables, will be presented.

\section{Re-examining the Concept of Energy Security}

The concept of energy security is a contested one (Kruyt et al. 2009, p. 2166). Chester (2010) calls it "polysemic," on the basis that it incorporates a range of potential meanings. In the energy security literature, there 
seem to be almost as many definitions as papers written on the topic. The lack of consensus about a definition makes it difficult to begin an analysis, so it is necessary here to conduct a brief discussion of the concept before presenting a suitable definition to serve the purposes of the paper.

Standard definitions of the energy security concept tend to refer to the so-called "four As" of "availability, accessibility, affordability and acceptability" (Cherp and Jewell 2014, p. 415), or conceptually similar terms. Yet such definitions are problematic, at least from the perspective of scholars of international relations (IR) and international politics, due to the emphasis on matters of supply, demand and cost, and the omission of (or apparent lack of concern with) geopolitical factors (for instance, Bhagat 2006, p. 95). While a number of scholars in the field of energy tend to focus on sustainability, reliability and cost in their definitions of the concept of energy security (see, for instance, Yergin 1988, p. 112; Barton et al. 2004, p. 5; Proedrou 2012, p. 3; and Wang 2006, p. 89|, many IR scholars would see the necessity of including other, potentially less clear-cut factors, such as hard (military) security and the state of diplomatic relations between customer and supplier nations.

There is also a need, as Cudworth and Hobden (2011) point out, to centralise environmental factors in developing what they call "posthuman international relations." Traditional expositions of energy security tend not to prioritise the health of the planet and the need to encourage cleaner approaches to energy supplies in order to enhance the collective security of all beings living within the biosphere. Attributing excessive weight to economic factors tends to lead to disregard for non-traditional security, resulting in what some economists have called "externalities," or damage to the environment. It is, therefore, necessary to develop a definition of energy security which takes account of non-traditional, as well as traditional, aspects of the concept in order to frame research in a more complete and theoretically satisfying manner.

For the purposes of this paper it is thus essential to include environmental, geopolitical and geo-economic factors (Li 2015, Zha 2006, Zweig and Bi 2005) into an expanded conceptualisation of energy security. Since the conventional energy security literature has covered issues related to cost and supply in depth, rethinking the traditionally narrow definition of the term permits us to broaden the scope of the analysis to take in factors emerging from non-traditional energy security. For the purposes of this paper, this deepening of the concept allows us to define energy security in terms of cost, supply and sustainability, but with the proviso that geopolitical and environmental factors also have a significant bearing on the problem. 


\section{A Brief History of Progress towards EU-China Energy Security Cooperation}

Although formal discussions between the EU and China were initiated as long ago as 1994, substantive progress on energy policy cooperation has been slow in coming. It was not until 2009 that the two actors issued a joint statement in the wake of the $12^{\text {th }}$ EU-China Summit which included an expression of will to cooperate on energy security, framed in terms of the goal to promote the use of renewable energy (Council of the European Union 2009). Subsequently, two joint declarations specifically dedicated to energy security were published in 2012 and 2013; but at the time of writing these have not resulted in any substantial progress, due mainly to a lack of political will and the resultant absence of action (EC2 2015, p. 21).

Other connected factors which impede substantive steps towards enhanced cooperation on energy security include "trade friction, ineffective cooperation mechanisms and a lack of mutual trust" (Yu 2016, p. 24). Trade friction, as far as Europeans are concerned, has generally revolved around accusations of Chinese dumping of manufactured goods and lack of access for European companies to Chinese markets. From the Chinese point of view, a major sticking point has been the EU's refusal to grant China Market Economy Status (MES). After China's accession to the World Trade Organization (WTO) in 2001, Beijing had understood that there was a deadline for MES to be granted to China by December 2016. However, the EU has refused to grant MES to China on the grounds that the assumed deadline was not legally binding and because China has not yet met the conditions to be considered a genuine market economy (Yu 2016).

In the sphere of energy, the most notable dispute has been the one over the alleged dumping by China of cheap solar panels in the European market, which Brussels claimed was negatively impacting European manufacturers: the dispute was more-or-less resolved (or at least dampened down) in July 2013 (Plasschaert 2016, p. 6). However, tensions over alleged Chinese dumping in the steel sector and other areas continue to simmer, meaning that attempts by the two parties to build a working relationship thus far have been stymied by the inability to generate an atmosphere of mutual trust.

With the advent of China's Belt and Road Initiative in a pair of speeches by President Xi Jinping in autumn 2013 and the launch in November 2014 of the EU's European Fund for Strategic Investment (popularly referred to 
as the "Juncker Plan," after European Commission President Jean-Claude Juncker), the potential for cooperation on energy security has increased considerably. Juncker's aim is to raise 315 billion euros in investment, some of which is to be earmarked for energy infrastructure: energy has been identified as a key strategic area for Europe's development (European Commission 2014b). China's Belt and Road Initiative is an ambitious plan to link Asia with Europe, the Middle East and Africa via both land and sea routes, and as such also involves proposed large-scale investment in infrastructure, not least in the field of energy. Already, China is investing in oil and gas pipelines, nuclear plants, hydroelectric dams and other energy infrastructure in Myanmar, Pakistan, Kazakhstan, Turkmenistan, Russia, East Africa and elsewhere. As Verlare and Van Der Putten (2015) point out, the two initiatives are potentially complementary, and work urgently needs to be done to identify ways to create synergies between the two.

From the European perspective, such cooperation should surely involve harnessing Chinese financial clout and economies of scale to enhance European energy infrastructure in a coordinated fashion. Already, Chinese companies are investing in major purchases of shares in selected European energy firms. The Chinese involvement in the construction of a new nuclear reactor at Hinkley Point in the UK (see below) represents another (albeit controversial) area of potential Europe-wide cooperation on energy. Further feasibility studies of possible Chinese involvement in energy infrastructure construction in the EU need to be conducted in order to ascertain which types of projects are realistic and desirable, and to what extent the presence of Chinese companies in Europe either creates synergies or damages local competitors.

On the other hand, given the vast geographical distance separating Europe and China, it may well be the case that opportunities to coordinate logistics regarding supplies and suppliers of oil, natural gas and other fossil fuels are limited. For each, the supply routes are different and, as the following sections will demonstrate, while the basic need to diversify energy supplies as far as possible is the same, the logistics of doing so are somewhat different. However, this paper argues that while the potential for cooperation on supplies of fossil fuels is rather limited, the possibilities regarding renewable energy are essentially limited only by the respective visions of the two putative partners; and therefore, for the sake not only of the energy security of each actor, but also for the well-being of the entire planet, should be vigorously pursued. 


\section{Energy Security in the European Union}

Despite only developing a coordinated energy policy relatively recently (the policy was approved by the European Council in 2005 and included in the 2007 Treaty of Lisbon), the EU has made significant progress towards improving its energy security in the last decade, in terms of reducing consumption and decreasing reliance on fossil fuels. According to data obtained from the Eurostat database, total energy consumption in the EU fell from 1.84 billion tonnes of oil equivalent (TOE) in 2006 to 1.61 billion TOE in 2014. Consumption of petroleum products was reduced from the 2004 high of 680 million TOE to 553 million TOE in 2014. Use of renewables increased steadily from just 72 million TOE in 1990 to 201 million TOE in 2014. So, despite one observer's claim that the EU's implementation of energy policy is "frequently too slow, incoherent and uncoordinated" (Umbach 2012, p. 107), there is statistical evidence of steady improvements to the energy mix and levels of consumption.

Breaking down the data further reveals that the EU remains heavily dependent on imports of oil and natural gas. 90 per cent of the EU's crude oil and 66 per cent of its natural gas are imported (European Commission $2014 a$, p. 2). Furthermore, a large proportion of these imports come from just two suppliers: Russia and Norway. In 2014, 69 per cent of natural gas imports and 43.5 per cent of oil imports came from these two countries (Eurostat). This data suggests that efforts to diversify the EU's energy mix and improve overall energy security have not yet been entirely successful and certainly require more impetus, particularly when one considers that the 2014 percentage of natural gas imports from Norway and Russia is slightly higher than that in 2004. Together, oil and natural gas still make up 59 per cent of the EU's energy mix (BP 2016).

Greater success has been achieved with regards to coal consumption. The EU's consumption of coal almost halved between 1990 and 2015 (Eurostat 2016) and now makes up 16 per cent of the EU's energy mix. Domestic production of coal has declined at an even faster rate, meaning that 74 per cent of coal supplies are now imported. However, since these supplies are highly diversified, sourced from a wide range of supplier countries, there is no significant security issue concerning coal supplies, at least in the traditional sense. On the other hand, in terms of non-traditional energy security, air pollution from coal use is still a concern, particularly in European countries (such as Poland) which remain heavy consumers of coal. 
Nuclear energy in the EU is a politically-charged and controversial issue. Germany is phasing nuclear energy out and replacing it with renewables, and France is aiming to halve its nuclear output by 2025 (Word Nuclear Association 2016). The UK is alone in seeking to expand its nuclear output, but due to the Brexit referendum in 2016, is scheduled to no longer be a member of the EU by 2020. Thus, the fact that, according to Eurostat, nuclear energy constituted 12 per cent of the EU's 2015 energy mix, is not as significant as it seems because this figure is certain to go down, particularly since almost half of the amount is produced and consumed in France, which is cutting its output.

Renewables made up 13 per cent of the EU's energy mix in 2015 (BP 2016). Of this, five per cent came from hydroelectric power, while wind power constituted 1.4 per cent and solar photovoltaic a mere half of one per cent of the overall mix. Most of the rest, according to Eurostat, came from solid biofuels (excluding charcoal). This means that there is still plenty of work to be done to boost the share of the most environmentally-friendly sources of renewable energy in the EU's overall energy mix, even though significant increases have been reported in all 28 current EU members since 1990, with Germany the leading producer in 2014.

The desirability of finding ways to produce lower cost renewables in larger quantities is obvious, although the scientific feasibility of such a project is less clear. At the present moment in time, the possibility of coordinating energy policy and research on renewables with China and its companies is one that needs to be researched carefully since there is a clear opportunity for the enhancement of energy security at both ends of the Eurasian landmass, as well as worldwide.

\section{Energy Security in China}

The first thing which needs to be noted about China's energy security is the nation's overwhelming dependence on coal. Although there is statistical evidence to suggest that peak coal consumption was reached in 2014, coal still makes up approximately two-thirds of China's energy mix (EIA 2015). The resultant air pollution is sufficiently serious to have necessitated the temporary closure of coal-burning factories in and around Beijing and other cities on several occasions when important international events were being hosted. The vast majority of coal is produced domes- 
tically, so there is no threat to energy security in the traditional sense; but both the Chinese government and Chinese citizens are keenly aware of the impacts of air pollution on public health and the subsequent need to reduce coal's share in the energy mix. Thus, the necessity to diversify away from coal has become a significant factor in China's energy security equation.

On the other hand, the picture concerning China's oil consumption looks somewhat different. China's rapidly rising thirst for oil in recent decades, and the fact, despite steadily increasing domestic production $\mathrm{Wu}$ 2014 , p. 6), that China has been a net oil importer since 1993, mean that higher oil use brings with it some energy security implications in the traditional sense. However, although oil constitutes 19 per cent of the energy mix (BP 2016), China has been relatively successful in diversifying supplies: in 2014, no single supplier delivered more than 17 per cent of China's imported oil, and 14 different nations supplied at least two per cent of the total (EIA 2015). Thus, China has managed its oil supply issues surprisingly well, particularly since Chinese companies have succeeded in developing new sources of oil such as Angola, which in 2014 was China's second largest supplier after Saudi Arabia.

Most of the imports, however, arrive by sea through the narrow Straits of Malacca and the South China Sea. China thus fears that its oil supplies could be cut off in the event of a major conflict, for example with the US, and is seeking to obtain a larger proportion of imports via pipelines, for instance from Russia and Central Asia. The maritime factor is also likely to be a motivation for China's aggressive island-building programme in the South China Sea, where the construction of new military installations may have the aim of protecting supply lines of oil and other commodities. However, it has been pointed out that it would be extremely difficult, given the existence of alternative maritime routes and the complex marine geography involved in such an enterprise, to totally blockade China's oil supplies (Erickson and Collins 2010). This means that Chinese fears about the energy import lifeline being cut off probably have a less rational basis than might at first appear to be the case. Thus, as with coal, the main energy security headache generated by high oil use is in fact the non-traditional one of air pollution generated by the ever-increasing traffic on the roads of Chinese cities, and the consequent damage not only to the environment, but also to Chinese people's health. 
Natural gas is, of course, a cleaner form of energy, and represents an obvious alternative to heavy coal and oil consumption, which together make up more than 80 per cent of China's energy mix. However, China is not well-endowed with gas and is therefore dependent on imports, particularly via pipelines from Central Asia. Liquid natural gas (LNG) can also be transported by sea from suppliers in Southeast Asia, but the amounts available are not unlimited. Due to the finite nature of potential imports, natural gas cannot realistically be a solution to China's coal and oil dependency conundrum.

This is probably the reason why China has elected to invest heavily into nuclear energy. In January 2017, China had 37 nuclear plants operating, with a further 20 being constructed (IAEA PRIS 2017). However, the rapid increase in output of nuclear energy is also unlikely to meet all, or even most, of the nation's growing and massive energy needs. British energy scholar Steve Thomas estimates that, even after completion of the construction programme, nuclear energy will not provide more than ten per cent of China's energy (Thomas 2016). In addition, building so many nuclear plants brings with it concomitant safety issues, implying that the most significant energy security issue connected to nuclear energy is ensuring that there is not a meltdown on the scale of the ones which occurred at Chernobyl and Fukushima.

By a process of logical elimination, this leaves the goal of improving and increasing renewable sources of energy as China's best hope of diversifying its polluting and potentially dangerous energy mix and enhancing its energy security. Already, China has become the world's number one producer of solar photovoltaic energy (Hill 2016), and wind power (Wu 2015 , p. 3). However, renewables still made up only ten per cent of China's energy mix in 2015, and 80 per cent of that figure came from hydroelectric power (BP 2016). Since China has already dammed nearly all its major rivers, there is limited potential to increase the output of hydroelectricity, and this means logically that China must look to expand other sources of renewable energy. This it has been doing as rapidly as possible, but clearly much more needs to be done. Since Chinese companies have been quickly acquiring stakes in renewable energy companies in Western Europe and elsewhere in the last two years (Ng 2016), and China and Europe have a similar need to increase the output and affordability of renewables, the time is obviously ripe for cooperation in a sector which has the potential to be a $21^{\text {st }}$ century game changer. 


\section{The Potential for Cooperation on Energy Security between the EU and China}

The preceding sections suggest that the highest potential for cooperation on energy security between the EU and China exists in the area of renewables, in particular wind power and solar photovoltaic. These two forms of energy currently constitute only a small part of Europe and China's energy mix, but one that is rapidly growing and which is demonstrating signs of becoming more cost effective worldwide as technologies improve and economies of scale kick in: for instance, in 2017 the price of solar power in India for the first time reached a level that was lower than that of fossil fuels, indicating the potential for renewables to outperform traditional energy sources (Safi 2017).

Conventionally, renewables are seen as loss-making, but the huge amount of capital being invested by Chinese companies in renewable energy acquisitions since 2014 suggests that these companies have a vision of renewables becoming increasingly not only profitable, but, in fact, a dominant industry during the course of the $21^{\text {st }}$ century (Jiang 2016). Joanna Lewis suggests that "[t]he role Chinese wind and solar industries have played in increasing total manufacturing scale has likely been a key contributor to global technological learning, with benefits for future deployment of these technologies around the world" (2014, p. 27). That this would be a desirable outcome goes without saying; but making it a reality will require a great deal of political will, business acumen and scientific research, not to mention collaboration on multiple levels.

As has already been implied in the preceding sections, the potential for cooperation in the sphere of conventional energy sources such as oil, coal and natural gas appears limited. The EU and China face rather different challenges regarding the sourcing of fossil fuels, with the EU looking to reduce dependency on Norway and Russia, while China tries to reduce its overwhelming dependency on coal and frets about its maritime supply routes. There might be thought to be some potential for cooperation on oil and gas pipelines, particularly those tapping Central Asian reserves; but political sensitivities about spheres of influence (particularly the Russian one) and cooperating with non-democratic regimes (as far as the Europeans are concerned) tend to undermine the notion of substantive collaboration. 
Nuclear energy is also problematic as far as Brussels is concerned, with both Germany and France trying to reduce the nuclear component in the European energy mix. There is therefore a lack of will to cooperate with Chinese nuclear companies, despite some overtures on their part and the fact of a Chinese company, China General Nuclear (CGN) being involved in the construction of a nuclear reactor at Hinkley Point in the UK in tandem with the French company EDF. Reports in the Chinese media of a proposed investment in the struggling French nuclear company Aveva (Song 2017) are also unlikely to meet with an enthusiastic response in Brussels. All in all, while the Chinese are constructing nuclear power plants at a fantastic pace, a major new drive towards large-scale use of nuclear energy in the EU is highly unlikely due to German and French resistance.

Renewables thus remain as the most probable arena for Sino-European cooperation in the area of energy security. Plasschaert suggests that China and the EU "have a common interest - as does the rest of the world - to speed up the advent of renewable energies ... cooperation in this vital area of public policy would allow turning the China-EU strategic partnership into a worthwhile reality instead of being tossed around as a loose slogan" (2016, p. 39). In the Chinese domestic market, China has already used economies of scale and technological innovations to lower costs and make renewables competitive with other forms of energy (Buckley and Nicholas 2017 , p. 1), which leads one to the conclusion that Europe should aim to take advantage of these advances and build on them in a coordinated fashion with the assistance of Chinese counterparts.

However, it seems that there is a lack of vision on the European side concerning the potential for renewables to become a leading power source in the $21^{\text {st }}$ century. There is also an underlying suspicion of the wisdom of letting China in (which could be termed the "Trojan horse syndrome"), which impedes cooperation, although some blame should also be attached to the Chinese for failing to communicate their aims with sufficient clarity and transparency. If the Belt and Road Initiative and the Juncker Plan can be coordinated and synergies between them discovered, there is the possibility of investing capital in research and development which utilizes European scientific and technical know-how and Chinese financial clout and business sense. This could generate a flourishing renewables industry which would be a $21^{\text {st }}$ century game-changer, and not just, as tends to be the view in Europe at present, a loss-making side-project. 


\section{Conclusion}

This paper contains two main arguments. The first is that energy security should not be viewed as concerned only with questions of cost, availability, sustainability and supply of fossil fuels, but should also take in non-traditional factors (at least as far as many mainstream energy scholars are concerned) such as the environment and the geopolitical context. It is important therefore to view energy security in terms of the whole energy mix, with the aim of achieving a better balance between traditional and non-traditional fuels. This implies that the emphasis should be on increasing the proportion of renewable sources of energy to benefit not only the EU and China, but also the energy security of the whole human race and the entire planet. Attitudes need to change in order that this aim becomes a realistic goal with achievable targets rather than simply being perceived as a rose-tinted vision of an imaginary future.

The second main argument of the paper is that the most likely area in which China and the EU will be able to collaborate on energy security is in the sphere of renewables. Logistical and geopolitical issues mean that establishing substantive cooperation on supplies of oil, natural gas and coal is difficult, while for a variety of reasons nuclear energy has become a non-starter in the corridors of Brussels. Renewables thus present the best opportunity for cooperation.

Ultimately, the major issue impeding cooperation is one of political will. On a scientific level, renewable energy technologies are beginning to achieve economies of scale. On a business level, Chinese companies appear willing to sink vast sums of capital into acquisitions and research. There is also no shortage of funding available via China's Asian Infrastructure Investment Bank and New Silk Road Fund, as well as potentially from the Juncker Plan. The question facing China and Europe is whether their leaders can get their heads together to coordinate the market potential, funds and technologies to create a plan for a future in which renewable energy transforms the energy security of the EU, China and, eventually, the whole world.

\section{References}

Barton, B., Redgwell, C., Rønne, A. and Zilman, D. 2004, Energy Security: Managing Risk in a Dynamic Legal and Regulatory Environment, Oxford: Oxford University Press. 
Bhagat, G. 2006, "Europe's energy security: challenges and opportunities," International Affairs, vol. 82, no. 5, pp. 961-975.

BP Statistical Review of World Energy 2016, https://www.bp.com/content/dam/bp/pdf/energy-economics/statistical-review-2016/bp-statistical-review-of-world-energy-2016full-report.pdf.

Buckley, T., and Nicholas, S. 2017, China's Global Renewable Energy Expansion: How the World's Second Biggest National Economy is Positioned to Lead the World in Clean-Power Investment, Institute for Energy Economics and Financial Analysis (IEEFA), January 2017, http://ieefa.org/wp-content/uploads/2017/01/Chinas-Global-Renewable-Energy-Expansion_January-2017.pdf.

Cherp, A., and Jewell, J. 2014, "The concept of energy security: beyond the four As," Energy Policy, vol. 75, pp. 415-421.

Chester, L. 2010, "Conceptualising energy security and making explicit its polysemic nature," Energy Policy, vol. 38, pp. 887-895.

Council of the European Union 2009, Joint Statement of the 12th EU-China Summit, Nanjing, November 30, http://www.consilium.europa.eu/uedocs/cms_Data/docs/ pressdata/en/er/111567.pdf.

Cudworth, E., and Hobden, S. 2011, Posthuman International Relations: Complexity, Ecologism and Global Politics, London: Zed Books.

Energy Information Administration (EIA) of the US 2015, China: international energy data and analysis, May 14, https://www.eia.gov/beta/international/analysis.cf$\mathrm{m}$ ? iso $=\mathrm{CHN}$.

Erickson, A.S., and Collins, G.B. 2010, "China's oil security pipe dream: the reality, and strategic consequences, of seaborne imports," Naval War College Review, vol. 63, no. 2, pp. 89-111.

EU-China Joint Declaration on Energy Security 2012, Brussels, May 3, https://ec.europa. eu/energy/sites/ener/files/documents/20120503_eu_china_joint_declaration_energy_security_en.pdf.

EU-China Joint Declaration on Energy Security 2013, Beijing, November 21, http://eeas. europa.eu/archives/delegations/china/documents/eu_china/131121_eu-china_joint_ declaration_energy_security_en.pdf.

European Commission 2014a, European Energy Security Strategy (Communication from the Commission to the European Parliament and the Council), May 28, http://eurlex.europa.eu/legal-content/EN/TXT/PDF/?uri=CELEX:52014DC0330\&from=EN.

European Commission 2014b, "EU launches Investment Offensive to boost jobs and growth" (press release), Strasbourg, November 26, http://europa.eu/rapid/press-release_IP-14-2128_en.htm.

Europe-China Clean Energy Centre (EC2) 2015, China-EU Energy Cooperation: Roadmap 2020, March, http://documents.rec.org/publications/EC2_roadmap_2020_EN_web.pdf.

Eurostat 2016, Statistics explained: coal consumption statistics, http://ec.europa.eu/eurostat/statistics-explained/index.php/Coal_consumption_statistics.

Garlick, J. 2017, "An elusive synergy: the quest for cooperation on energy security between China and the European Union," Issues e Studies, vol. 53, No. 3.

Hill, J.S. 2016, "China overtakes Germany to become world's leading solar PV country," CleanTechnica.com, January 22, https://cleantechnica.com/2016/01/22/china-overtakes-germany-become-worlds-leading-solar-pv-country/.

International Atomic Energy Association (IAEA) Power Reactor Information System (PRIS) 2017, Country Statistics for People's Republic of China, January 26, https://www.iaea. org/pris/CountryStatistics/CountryDetails.aspx?current $=\mathrm{CN}$. 
Jiang, X. 2016, "More Chinese firms seek green energy investment overseas," China Daily, May 12, http://europe.chinadaily.com.cn/business/2016-05/12/content_25232567. htm.

Kruyt, B., van Vuuren, D.P., de Vries, H.J.M., and Groenenberg, H. 2009, "Indicators for energy security," Energy Policy, vol. 37, no. 6, pp. 2166-2181.

Lewis, J.I. 2014, "The rise of renewable energy protectionism: emerging trade conflicts and implications for low carbon development," Global Environmental Politics, vol. 14, no. 4, pp. 10-35.

Li, J. 2015, "China emerging as a game changer in contention for global energy governance," Issues et Studies, vol. 51, no. 4, pp. 1-32.

$\mathrm{Ng}$, E. 2016, "China's clean-energy giants on an overseas shopping spree," South China Morning Post, December 12, http://www.scmp.com/business/companies/article/2053910/chinas-clean-energy-giants-overseas-shopping-spree.

Plasschaert, S. 2016, "Assessing the solar energy dispute between the European Union and the People's Republic of China," ECIPE (European Centre for International Political Economy) Working Paper, No. 01/2016, http://ecipe.org/app/uploads/2016/04/ ECIPE-Paper_Solar-Panel_Anti-Dumping_EU-China_final.pdf.

Proedrou, F. 2012, EU Energy Security in the Gas Sector: Evolving Dynamics, Policy Dilemmas and Prospects, Farnham, UK: Ashgate.

Safi, M. 2017, "Indian solar power prices hit record low, undercutting fossil fuels," The Guardian, May 10, https://www.theguardian.com/environment/2017/may/10/indian-solar-power-prices-hit-record-low-undercutting-fossil-fuels.

Song, S. 2017, "Chinese deal with French firm Areva lends credibility to country's nuclear sector," Global Times, January 12, http://www.globaltimes.cn/content/1028557. shtml.

Thomas, S. 2016, "China's nuclear power plans melting down," The Diplomat, October 29, http://thediplomat.com/2016/10/chinas-nuclear-power-plans-melting-down/.

Verlare, J., and van der Putten, F.P. 2015, "'One Belt, One Road': an opportunity for the EU's security strategy," Clingendael Policy Brief, December, http://www.clingendael. nl/sites/default/files/One_belt_one_road_vdPutten_Verlare_Clingendael_policy_ brief_2015.pdf.

Wang, Q. 2006, "Energy conservation as security," China Security, Summer volume, pp. 89-105.

World Nuclear Association 2016, Nuclear Power in France, November update, http://www. world-nuclear.org/information-library/country-profiles/countries-a-f/france.aspx.

Wu, G. 2015, "Wind matters: China's role in the future of wind," presentation at WWEC 2015, October 28, Israel, http://www.worldwindconf.net/wp-content/uploads/2015/11/Wu-Gang.pdf.

Wu, K. 2014, "China's energy security: oil and gas," Energy Policy, vol. 73, pp. 4-11.

Yergin, D. 1988, "Energy security in the 1990s," Foreign Affairs, vol. 67, no. 1, pp. 110-132.

Yu, K. 2016, "The EU as a partner in Chinese energy security in the era of climate change: drivers and challenges," EU-China Observer, no. 2.16, pp. 24-28.

Zha, D. 2006, "China's energy security: domestic and international issues," Survival, vol. 48 , no. 1, pp. 179-190.

Zweig, D., and Bi, J. 2005, "China's global hunt for energy," Foreign Affairs, vol. 84, no. 5, pp. 25-38. 